cation necessary for using Crosby Hall is membership of a national federation of university women, but residence is in general limited to one year, preference being given to research and postgraduate students. Members are welcomed for short visits and, accom. modation permitting, university women working in London can also live at Crosby Hall. The range of nationalities, professions and interests represented at the Hall is exceedingly varied, and all who have stopped there praise the spirit of international co-operation and tolerance that prevails. The demand for accommodation is very great, and an endowment fund has been launched to build a second residential wing, a library and additional common rooms, and also to endow fellowships. The first Crosby Hall scholarship from the new fund was awarded this year to Dr. Leonor Fiorini of Buenos Aires, Argentine, who specializes in hydro-geology, and two further scholarships have been endoweda City of London scholarship and a New Zealand one. New Zealand and Canada have each contributed $£ 1,000$ to the fund. An international sale to raise a further $£ 4,000$ will be held at Caxton Hall, London, S.W.1, on November 15, from noon to 7 p.m. (admission 1s.). $H=$

\section{Petroleum Plant at Stanlow}

A SMALL booklet, some eighty pages in length, and entitled "Britain's New Industry: Stanlow 1949", has been published by tho-Shell Chemical Manufacturing CoLtd., and ols scribes the oil installation and refing plant at Standyw, which was established on the south ank (we the Manchester Ship Canal in 1920 The booklet deals with the production of varipud kifds of oils, wax cracking, ester salts ('Tdepol'), and similar products and chemicals obtained from petroleum. It gives a popular account of the plant and processes, and is profusely illus. trated. The cracking processes are described in outline, for example, that for the production of iso. propyl and secondary butyl alcohols. The uses of the products are described. The processes used in America are also outlined, such as the production from propylene of allyl chloride, which is a raw material for the manufacture of plastics and synthetic glycerol. Butylene gives butadiene, the main raw material for the manufacture of synthetic rubber. At the end of the book there is a simple scheme of the chemistry of the processes which may be of interest to elementary students of organic chemistry and to business men. The production is very lavish, many of the illtrations being in colour.

\section{Predatory Birds of Great Britain}

Bezreving that ithere is a lack of knowledge throughout the country about the laws concerning the protectipuryef wild birds, and especially the predatory bir $\$$, the British Field Sports Society has prepared 2 useful guide to show clearly the protection whith thd law afiords them county by county. The book contains a clear description of each species, including measurements, range and habits, and in many cases drawings are included of the birds both settled and on the wing. It is also indicated which species, in the Society's opinion, are harmful and which are not. In the first category are those birds which, by reason of their numbers or habits, do very considerable damage not only to game birds, but also to song birds. Examples of these are the jay, magpie and sparrow-hawk. In the second category are those predatory birds such as harriers, kites and buzzards which, either because of their habits or their rarity, do little or no damage to the game preserver or the agriculturist. The booklet also includes tables showing the protection afforded county by county according to the Wild Birds Protection Acts. The handbook may be obtained from the British Field Sports Society, 51 Victoria Street, London, S.W.1, price $3 s$.

\section{Announcements}

The second Progress Medal of the Photographic Society of America has been awarded to Mr. J. Dudley Johnston, for inspiring leadership and fostering photogtaphic societies. The Medal, which is the highest, award in the gift of the Society, was received, on Nir. Johnston's behalf, by Mr. Joseph Dombroff, at the annual convention in St. Louis, on October 21. zir. Dombroff also read Mr. Johnston's Progress Medal Lecture entitled "Photography and Progress."

Prof. Herbyert Dingle, professor of the history and philosopky of science, University College, London, will delive a Norman Lockyer Lecture, arranged by the University of Birmingham and the British Assogration for the Advancement of Science, on Norember 22, in the Medical Theatre, University, Edmund Street, Birmingham. $\mathrm{He}$ will speak on "Modern Theories of the Origin of the Universe".

THE American Association for the Advancement of Science will hold its 116th meeting in New York City during December 26-31. Dr. Edmund W. Sinnott, of Yale, is retiring president of the Assoeiation, and Dr. Elvin C. Stakman, of the University of Minnesota, is president. Dr. Howard A. Meyerhoff is administrative secretary with headquarters at 1515 Massachusetts Avenue, N.W., Washington 5, D.C.

THE British Institute of Management, 17 Hill Street, London, W.1, has arranged a conference on current industrial problems such as incentives for management in the Welfare State, minimum wages, trajning for management, etc., to be held at Harrogate during November 17-20. Copies of papers are being circulated in advance to afford the maximum time for discussion.

THE Commissioners for the Exhibition of 1851 are compiling a centenary edition of their "Record of Science/Research Scholars", which includes the names and careers of all who have held research awgrds given by them. Requests for particulars of their careers have been forwarded to all Scholars for whom the Commissioners have an address ; but there remain some with whom it has not been possible to get into touch. Any past Scholar who has not received the printed request should communicate with the Secretary, Royal Commissioners for the Exhibition of 1851, I Lowther Gardens, Exhibition Road, London, S.W.7.

A WEEK-END conference on "Secrecy in Science" is being organised by the Cambridge Scientists' AntiWar Group and will be held during November 19-20 in Kecture Room 4, St. John's College, Cambridge. The meeting on November 19 opens at 2.30 p.m., and that on November 20 at 10 a.m. The conference will be open to all who are interested, and written contribytions will be welcomed.

EвкатUM. In the communication by Dr. F. G. Mann in Nature of November 5, p. 785, the word '-quinolino-' was incorrectly printed throughout : thus the title should read "Structure and Colour in the $1: 2$-Dihydro-quinolino $\left(3^{\prime}: 2^{\prime}: 3: 4\right)$ quinolines". 